\title{
INSIGHT INTO THE POTENTIAL INFLUENCE OF INTER-AND INTRA-INDIVIDUAL VARIABILITY OF TACROLIMUS EXPOSURE ON GRAFT FUNCTION DECLINE IN THREE-YEAR PERIOD FOLLOWING KIDNEY TRANSPLANTATION
}

\author{
NIKOLA Z. STEFANOVIĆ ${ }^{1 *}$, RADMILA M. VELIČKOVIĆ-RADOVANOVIĆ ${ }^{2,3}$, KATARINA S. \\ DANKOVIĆ $^{4}$, ALEKSANDRA K. CATIĆ-DJORDJEVIĆ ${ }^{1}$, IVANA D. DAMNJANOVIĆ ${ }^{1}$, \\ BRANKA P. MITIĆ ${ }^{3,5}$, MINA B. CVETKOVIĆ 3,4 , TATJANA P. CVETKOVIĆ 3,6 \\ ${ }^{1}$ University of Nis, Faculty of Medicine, Department of Pharmacy, 81 Dr Zorana Djindjica Boulevard, 18000, Nis, Serbia \\ ${ }^{2}$ University of Nis, Faculty of Medicine, Department of Pharmacology with Toxicology, 81 Dr Zorana Djindjica Boulevard, \\ 18000, Nis, Serbia \\ ${ }^{3}$ Clinical Centre Nis, Clinic of Nephrology, 48 Dr Zorana Djindjica Boulevard, 18000, Nis, Serbia \\ ${ }^{4}$ University of Nis, Faculty of Medicine, 81 Dr Zorana Djindjica Boulevard, 18000, Nis, Serbia \\ ${ }^{5}$ University of Nis, Faculty of Medicine, Department of Internal Medicine, 81 Dr Zorana Djindjica Boulevard, 18000, Nis, Serbia \\ ${ }^{6}$ University of Nis, Faculty of Medicine, Department of Biochemistry, 81 Dr Zorana Djindjica Boulevard, 18000, Nis, Serbia \\ *corresponding author: nikola.stefanovic@medfak.ni.ac.rs
}

Manuscript received: December 2019

\begin{abstract}
The main goal of the present study was to evaluate the association of tacrolimus (Tac) exposure parameters (trough concentration (TTC), dose-adjusted TTC (Co/D)), Tac intra-individual variability (IPV), and Tac-related gene polymorphisms (CYP3A5 and ABCB1) with kidney function in three-year period after kidney transplantation (Tx). The study enrolled 103 Caucasian patients who were genotyped on CYP3A5 6986A $>\mathrm{G}$ and ABCB1 3435C $>\mathrm{T}$ polymorphism. High IPV, lower average $\mathrm{C}_{0} / \mathrm{D}$, kidney function at 6 months post-transplantation, and acute rejection were independent predictors of worse eGFR values between 13 and 36 months after Tx. Significant eGFR decline was observed in the low $\mathrm{C}_{0} / \mathrm{D}(\mathrm{p}=0.010)$ and high IPV patients' group $(\mathrm{p}=0.018)$ between $13-24$ and 25 - 36 months. The carriers of CYP3A5*1 allele had lower $\mathrm{C}_{0} / \mathrm{D}$ values compared to the CYP3A5*3/*3 carriers during entire observation period, while ABCB1 3435 gene polymorphism did not affect $\mathrm{C}_{0} / \mathrm{D}$. Tailoring Tac treatment based on IPV, $\mathrm{C}_{0} / \mathrm{D}$ and CYP3A5 genotype in clinical practice may identify patients at risk for graft function decline.
\end{abstract}

\section{Rezumat}

Scopul principal al prezentului studiu a fost de a evalua asocierea parametrilor de expunere la tacrolimus (Tac) (concentrație minimă (TTC), TTC ajustată la doză (Co/D)), variabilitatea intra-individuală a Tac (IPV) și polimorfismul genetic determinat de Tac (CYP3A5 și ABCB1), cu funcția renală pe o perioadă de trei ani după transplantul renal (Tx). Studiul a înrolat 103 pacienți caucazieni care au fost genotipați (polimorfismul CYP3A5 6986A $>\mathrm{G}$ și ABCB1 3435C $>\mathrm{T}$ ). IPV ridicat, $\mathrm{C}_{0} / \mathrm{D}$ mediu mai scăzut, funcția renală la 6 luni după transplant și respingerea acută au fost predictori independenți ai valorilor eGFR mai slabi între 13 şi 36 de luni după Tx. Scăderea semnificativă a eGFR a fost observată în grupul de pacienți cu $\mathrm{C}_{0} / \mathrm{D}$ scăzut $(\mathrm{p}=$ $0,010)$ și în grupul de pacienți cu IPV ridicat $(p=0,018)$ între $13-24$ și 25 - 36 de luni. Purtătorii alelei CYP3A5*1 au avut valori $\mathrm{C}_{0} / \mathrm{D}$ mai mici comparativ cu purtătorii $\mathrm{CYP} 3 \mathrm{~A} 5 * 3 / * 3$ pe întreaga perioadă de observație, în timp ce polimorfismul genei $\mathrm{ABCB} 13435$ nu a afectat $\mathrm{C}_{0} / \mathrm{D}$. Adaptarea tratamentului Tac bazat pe genotipul IPV, $\mathrm{C}_{0} / \mathrm{D}$ și CYP3A5 în practică poate identifica pacienții cu risc de rejectare a grefei.

Keywords: tacrolimus, pharmacokinetic variability, kidney function, kidney transplantation

\section{Introduction}

Tacrolimus (Tac) is a cornerstone of the most immunosuppressive protocols after kidney transplantation (Tx) worldwide, but its clinical use is complicated by narrow therapeutic index and large inter-individual variability in pharmacokinetics. Therapeutic drug monitoring (TDM) is routinely performed to maintain Tac trough concentration (TTC) within an optimal range with a view to reduce toxicity and improve the efficacy of immunosuppressive treatment [8, 23]. Still, some patients will experience adverse effects or lack of efficacy with the TTC within the optimal range, which suggests that further investigation of factors that contribute to these disadvantages is required $[1,16]$. Studies showed that genetics along with demographic factors and drug-drug interactions are the main contributors to Tac inter-individual pharmacokinetic variability [22, 23, 31]. Furthermore, it is assumed that cytochrome $\mathrm{P} 450$ (CYP) 3A5 6986A $>\mathrm{G}$ gene polymorphism is the 
major determinant of the aforementioned variability, thus influencing different Tac, daily dose (TDD) requirements among individuals $[13,24]$. Tacrolimus is a substrate for the efflux P-glycoprotein (P-gp) coded by the gene ABCB1, which is highly polymorphic [31]. Following CYP3A5, the 3435C>T within the ABCB1 gene has been the second most studied polymorphism associated with Tac pharmacokinetics, but its contribution to the inter-individual variability of Tac has not been completely confirmed [5, 29]. Still, whether these polymorphisms have an impact on kidney transplant function or not, is not elucidated entirely [9, 13, 29]. Besides well-known inter-individual variability, Tac is characterized by marked intra-individual variability (IPV) in drug exposure, defined as the fluctuation in TTC within an individual patient over a certain period of time during which TDD remains constant. Low adherence, drug-drug interactions, and food mostly contribute to the high IPV, while the influence of genetic factors is less important when compared to the inter-individual pharmacokinetic variability of Tac [21]. Patients with high IPV of Tac are more prone to sub- and supra-therapeutic drug concentrations than recipients with low IPV. Besides, it is demonstrated that high Tac IPV may be a significant predictor of chronic allograft injury after Tx, including transplant rejection. Most of these events assumed to happen within two years post-transplantation [20]. The main goal of this study was to evaluate the association of Tac exposure parameters (TTC, dose-adjusted TTC $\left.\left(\mathrm{C}_{0} / \mathrm{D}\right)\right)$, Tac IPV, and Tac-related gene polymorphisms (CYP3A5 and ABCB1) with kidney function (defined for this study as estimated glomerular filtration rate (eGFR)) in the long-term period after Tx. Furthermore, it was investigated whether Tac IPV and/or $\mathrm{C}_{0} / \mathrm{D}$ might have influenced the progression of kidney function decline or not, in a three-year period following Tx. In addition, the goal was to compare the distribution of TTC within and beyond the target therapeutic range (6 - $10 \mathrm{ng} / \mathrm{mL}$ ) in relation to Tac IPV.

\section{Materials and Methods}

\section{Study design}

The single-centre pharmacokinetic-pharmacogenetic study was conducted at the Research Centre for Biomedicine, Faculty of Medicine, University of Nis and the Clinic of Nephrology, Clinical Centre Nis, Nis, Serbia. All procedures performed in studies involving human participants were in accordance with the ethical standards of the institutional and/or national research committees and with the 1964 Helsinki Declaration and its later amendments or comparable ethical standards. The protocols were approved by the Ethics Committee of Faculty of Medicine, University of Nis (No 122307-2/5 from 10.03.2016. and No 12-6972-2/5 from 02.07.2018).
The study included 103 Caucasian patients who underwent the first transplantation surgery between 2008 and 2016. All patients had their routine controls, including TDM of Tac and biochemical monitoring, at the Clinic of Nephrology, Clinical Centre Nis, Serbia. The present study followed the period from 6 up to 36 months after Tx and included 2530 patients' examinations when TTC was determined (24.5 per patient). The kidney transplant recipients met some exclusion criteria before they were enrolled into this study and therefore we excluded patients who underwent $\mathrm{Tx}$ less than 3 years ago, with any sign of graft failure demanding regular dialysis within the first posttransplantation year, and with uncontrolled hypertension. Of patients enrolled into the study, 66 were men and 37 were women, mean age $39.41 \pm$ 10.77 at the beginning of the study, 74 patients had living donor transplantation (LDT), while 29 got transplanted kidney from deceased donors (DDT). Regarding Tac pharmaceutical formulation, 78 patients were prescribed conventional preparation, immediate-release hard capsules (Prograf ${ }^{\circledR}$, Astellas Ireland Co. Ltd.), which were administered twice-aday (Tac-TD) or prolonged-release hard capsules (Advagraf $^{\circledR}$, Astellas Ireland Co. Ltd.), which were administered once-a-day (Tac-OD). The data used in the study were taken from the medical records of kidney transplant recipients. In order to protect patient data, each patient was assigned a code at the beginning of the study, which was used in statistical analysis instead of the patient's name.

Immunosuppressive protocol. All patients started with a quaternary immunosuppressive protocol that besides Tac included intravenous methylprednisolone, with an initial dose of $0.5 \mathrm{~g} /$ day which was later switched to prednisone ((PRE), initial dose of $1 \mathrm{mg} / \mathrm{kg} \mathrm{bw} /$ day, mycophenolate mofetil (MMF), 1.5 - 2 g/day or mycophenolic acid (MPA), 1080 - 1440 mg/day orally and $20 \mathrm{mg}$ of monoclonal antibody basiliximab which was administered at the first and the fourth day after Tx. The first oral Tac dose was administered on day 5 post-transplantation at $8.00 \mathrm{~h}$ before breakfast $(0.1$ $\mathrm{mg} / \mathrm{kg}$ bw or $0.2 \mathrm{mg} / \mathrm{kg}$ bw). Furthermore, Tac was administered twice-daily ( $08.00 \mathrm{~h}$ and $20.00 \mathrm{~h}$ ) or oncedaily $(08.00 \mathrm{~h})$ depending on the prescribed drug, and the dose was adjusted according to the TDM in order to achieve target therapeutic range of $8-12 \mathrm{ng} / \mathrm{mL}$ for the first 90 days and $6-10 \mathrm{ng} / \mathrm{mL}$ afterwards. Besides standard immunosuppressive therapy, patients also received antihypertensive drugs: beta blockers (bisoprolol, carvedilol or metoprolol) and/or calcium channel blockers (amlodipine) in monotherapy as well as in the combination. In addition some patients received angiotensin-converting enzyme (ACE) inhibitors (fosinopril and zofenopril). All patients were prescribed omeprazole, pantoprazole or ranitidine as gastroprotective. 
Biochemical monitoring. Routine biochemical parameters, such as serum level of albumin (ALB), total proteins (TP), glucose (GLU), blood urea nitrogen (BUN) and creatinine (CRE) were measured by standard methods in the Biochemical laboratory of the Clinic of Nephrology. Analyses were performed on an automated random access clinical chemistry analyser (ERBA XL-600, ERBA Diagnostics Mannheim GmbH, Mannheim, Germany). The Modification of Diet in Renal Disease (MDRD) equation was used for the calculation of eGFR [15]. The body mass index (BMI) was also calculated. Data regarding acute rejection (AR) within the first year and delayed graft function (DGF) were obtained from medical records.

Pharmacokinetic data. For the purpose of analysis, the following data were collected: TDD, TTC, and $\mathrm{C}_{0} / \mathrm{D}$. The TDD was obtained from the medical records or in oral communication with patients, while TTC was measured by chemiluminescent microparticle immunoassay method according to the manufacturer's instructions (Architect, Abbott, Abbott Park, IL, USA). Doseadjusted trough concentration was calculated as TTC divided by the corresponding TDD. It represents a surrogate index of Tac bioavailability. We recorded TDD and TTC during the entire observation period of three years post-transplantation.

Intra-individual pharmacokinetic variability. Since TDD was not fixed, especially in the early phase after $\mathrm{Tx}, \mathrm{C}_{0} / \mathrm{D}$ instead of TTC was used for IPV calculation, although in most patients, we preferred periods with constant TDD during 6 - 12 months posttransplantation. Tacrolimus IPV was calculated as the coefficient of variation (CV\%) of the $\mathrm{C}_{0} / \mathrm{D}$ between 6 and 12 months after Tx (formula):

$$
C V \%=\frac{\bar{x}}{S D} \times 100 \%,
$$

where $\bar{x}$ is the mean $\mathrm{C}_{0} / \mathrm{D}$ of available samples during 6 - 12 months after Tx, calculated for each patient; SD-standard deviation of available samples during 6 - 12 months after Tx, calculated for each patient; Average number of TTC used for IPV calculation was 7 per patients, range 4 - 11. Data from patient's hospitalization were not included.
Genotyping CYP3A5 and ABCB1 polymorphism. A fasting blood sample was taken from each patient during the routine control at the Clinic. Of the whole blood sample, $200 \mu \mathrm{L}$ was used for DNA isolation. DNA was extracted from the whole blood with EDTA as an anticoagulant using Genomic DNA Purification Kit (Fermentas, Thermo Scientific, Lithuania) according to the manufacturer's instructions. CYP3A5 6986A>G (rs776746) genotyping was performed using TaqMan ${ }^{\circledR}$ Drug Metabolism Genotyping Assays for CYP3A5*3 (C_26201809_30) (Applied Biosystems, Carlsbad, CA, USA) on the Mx3005P Real-Time PCR System (Agilent Technologies), according to the manufacturer's instructions. ABCB1 3435C>T (rs1045642) genotyping was performed by allele-specific PCR method [2, 24]. Statistical analysis. The distribution of genotypes for each polymorphism was assessed for deviation from Hardy-Weinberg equilibrium (HWE). The characteristics of the study group were expressed as median and interquartile range or number. The general linear model-repeated measures, with Bonferroni Post Hoc Test (for normally distributed data) or Friedman test, with Wilcoxon Test (not normally distributed data) was performed to estimate the change in eGFR within patients with the same IPV and $\mathrm{C}_{0} / \mathrm{D}$ group in different periods after Tx. Mann-Whitney U test (not normally distributed data) was employed for the comparison of TDD, TTC and $\mathrm{C}_{0} / \mathrm{D}$ with respect to CYP3A5 and $\mathrm{ABCB} 1$ genotype. Chi-square $(\chi 2)$ test was used to compare data between groups, when data were defined as categorical. Linear regression analysis was performed to evaluate the potential influence of independent predictors on eGFR. All analyses were performed using SPSS statistical analysis software, version 20.0 (SPSS, Chicago, IL, United States) at the significance level set at $\mathrm{p}<0.05$.

\section{Results and Discussion}

The characteristics of the study participants are given in Table I. Genotype frequencies did not deviate from HWE ( $p>0.05$ ) for tested polymorphisms: CYP3A5: Chi-Square $=0.64, \mathrm{p}=0.43$ and ABCB1: Chi-Square $=$ $0.78, \mathrm{p}=0.38$.

Table I

Characteristics of the study population in different periods after Tx

\begin{tabular}{|c|c|c|c|}
\hline & 6 - 12 months & 13 - 24 months & 25 - 36 months \\
\hline SEX (Male/Female) & & $66 / 37(64 \% / 36 \%)$ & \\
\hline TX TYPE (LDT/DDT) & & $74 / 29(72 \% / 28 \%)$ & \\
\hline Age (years)* & & $39(31-47)$ & \\
\hline Body mass (kg) & $72.0(62.5-80.0)$ & $72.5(65.0-81.0)$ & $72.0(63.0-81.0)$ \\
\hline BMI $\left(\mathrm{kg} / \mathrm{m}^{2}\right)$ & $23.73(22.21-26.11)$ & $24.28(22.58-27.06)$ & $24.30(22.22-27.69)$ \\
\hline CRE $(\mu \mathrm{mol} / \mathrm{L})$ & $131(112-158)$ & $122(106-151.50)$ & $129(105-161.50)$ \\
\hline eGFR $\left(\mathrm{mL} / \mathrm{min} / 1.73 \mathrm{~m}^{2}\right)$ & $48.09(38.86-56.89)$ & $50.02(40.79-58.71)$ & $49.24(36.74-58.64)$ \\
\hline BUN (mmol/L) & $7.60(5.80-9.80)$ & $7.20(5.50-9.30)$ & $7.60(5.60-9.70)$ \\
\hline GLU (mmol/L) & $5.05(4.60-5.70)$ & $5.03(4.60-5.60)$ & $5.05(4.60-5.70)$ \\
\hline $\operatorname{ALB}(\mathrm{g} / \mathrm{L})$ & $41(38-44)$ & $41(39-43)$ & $41(38-43)$ \\
\hline $\mathrm{TP}(\mathrm{g} / \mathrm{L})$ & $71(67-75)$ & $71(67-74)$ & $71(68-75)$ \\
\hline CYP3A5 genotype: $* 1 / * 1 ; * 1 / * 3 ; * 3 / * 3$; & & $0 / 15 / 88$ & \\
\hline
\end{tabular}




\begin{tabular}{lc}
\hline \hline ABCB1 3435: CC;CT;TT; & $29 / 47 / 27$ \\
\hline Acute graft rejection (no/yes) & $98 / 5(95.1 \% / 4.9 \%)$ \\
\hline Delayed graft function (no/yes) & $90 / 13(87.4 \% / 12.6 \%)$ \\
\hline
\end{tabular}

Data are expressed as median (IQR) or number

* - age at the beginning of the study; ** - mycophenolate mofetil dose was calculated on mycophenolic acid dose

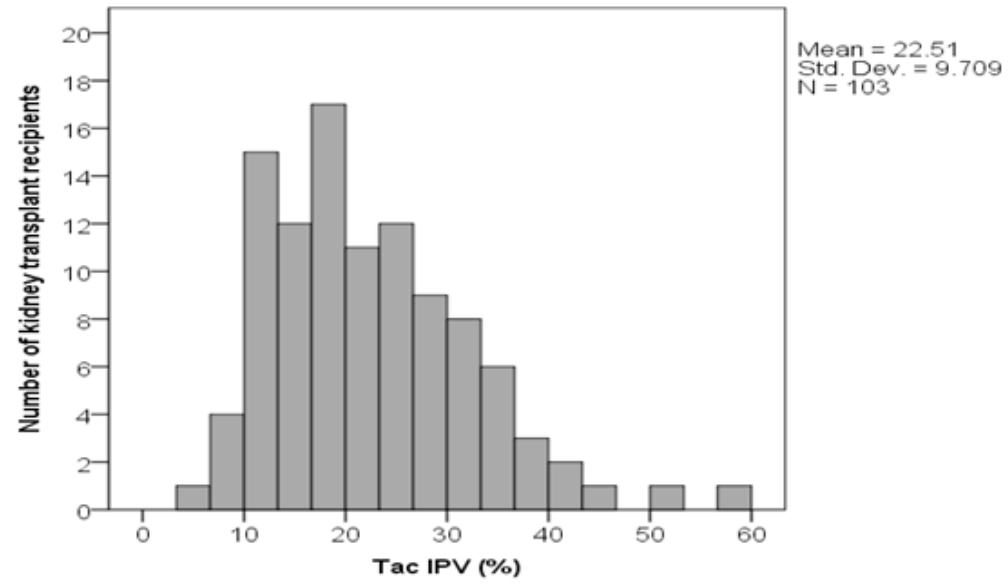

Figure 1.

Distribution of Tac IPV in the study population

Figure 1 shows the distribution of Tac IPV among kidney transplant recipients. For the purpose of further analysis, patients were divided into three equal groups based on Tac IPV tertiles, low-IPV tertile group: $<17.73 \%(12.77 \pm 2.64 \%)$, middle-IPV tertile group: $17.73-25 \%(21.20 \pm 2.21 \%)$, and high-IPV tertile group: $>25 \%(33.61 \pm 7.27 \%)$.

The growing number of clinical studies supports the fact that intra-individual (i.e. intra-patient) variability in Tac exposure correlates with inferior long-term kidney transplantation outcomes [11, 14, 25]. The previous studies showed a wide range of Tac IPV, with some individuals having a Tac IPV of $<5 \%$, whereas the others having variability of $>50 \%$, but with an average Tac IPV between $15 \%$ and $30 \%$ [20], which is in accordance with this study (Figure 1).
Patients with highly fluctuated Tac concentrations are at risk either for underexposure and rejection or overexposure and Tac toxicity [14]. Therefore, Figure 2 demonstrates an estimation of the potential change in eGFR values at successive time periods after Tx with respect to IPV tertiles. The obtained results showed no difference in eGFR values between observed post-transplantation periods in low-IPV $(\mathrm{p}=0.389)$ and middle-IPV ( $p=0.141)$ tertile patients group. Conversely, a change in eGFR was observed in the high-IPV tertile group ( $\mathrm{p}=0.018$ ), whereby pairwise comparisons indicated a significant difference between $13-24$ and $25-36$ months after Tx $(47.92 \pm 15.79$ $\mathrm{mL} / \mathrm{min} / 1.73 \mathrm{~m}^{2}$ vs. $45.32 \pm 16.40 \mathrm{~mL} / \mathrm{min} / 1.73 \mathrm{~m}^{2}$, $\mathrm{p}=0.018)$.

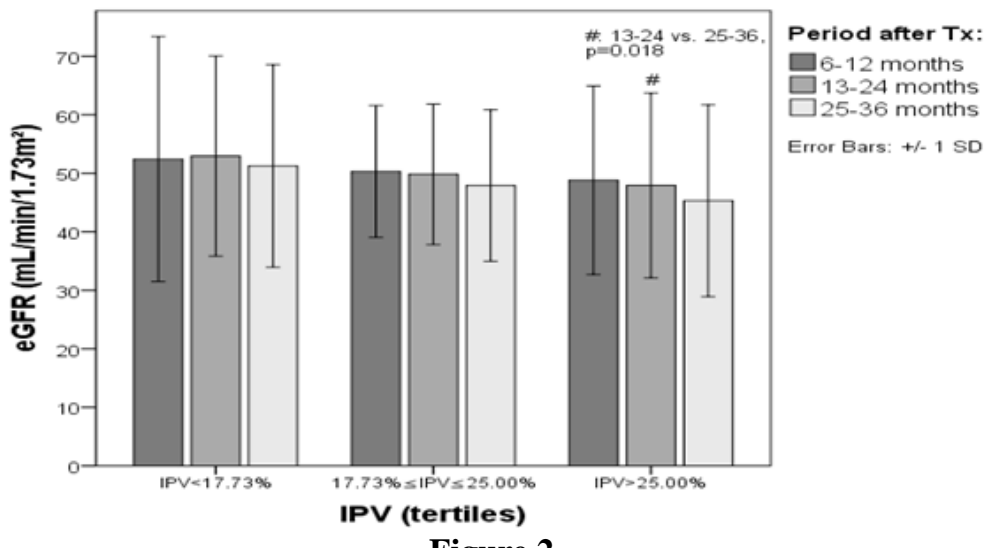

Figure 2.

Change in eGFR values in different periods after Tx with respect to Tac IPV tertiles

The present study demonstrated that patients in high tertile IPV group (IPV > 25\% mean: $33.61 \pm 7.27 \%$ ) had a more progressive reduction in eGFR between second and third post-transplantation year compared to low and middle tertile IPV group of patients. Clinical importance of IPV was first obtained by Borra et al., 
FARMACIA, 2020, Vol. 68, 6

in a study with the mean follow-up of $1849 \pm 585$ days and a population consisting of 263 controls and 34 failures. They demonstrated that high IPV is closely associated with a composite endpoint consisting of graft loss, biopsy-proven chronic allograft nephropathy and doubling of plasma creatinine concentration [4]. Shuker et al. have expanded the study of Borra $e t$ $a l$., and showed in a cohort of 808 kidney transplant recipients, that high IPV patients had a 1.4 times higher risk of reaching the composite endpoint (i.e. late acute rejection, transplant glomerulopathy, graft loss, or doubling of serum creatinine) [20]. In both studies, the median value of IPV was used as a cutoff for the selection of patients into low and high IPV group. De novo donor-specific antibodies (dnDSA) and consequently antibody-mediated allograft injury have directly and indirectly been linked to Tac IPV and Tac underexposure [14]. Rodrigo et al. focused on the relationship between Tac IPV and the incidence of dnDSA and death-censored graft loss (DCGL). High IPV $(\mathrm{CV} \%=30 \%)$ was the strongest risk factor for dnDSA development and DCGL, as acute rejection and re-transplantation, whereas mismatches, age, sex and mean Tac levels were not related to dnDSA development [17]. Recently, Kaya Aksoy et al. showed that high Tac IPV influenced the formation of antiHLA antibody in paediatric recipients of living-donor kidney transplants [10].

Considering the distribution of TTC beyond and within the target therapeutic range $(6-10 \mathrm{ng} / \mathrm{mL})$, most of the TTC $<6 \mathrm{ng} / \mathrm{mL}$ during $6-12$ months posttransplantation were observed in the high-IPV group (> 40\%; Chi-Square $=25.175, \mathrm{p}<0.001)$. Similar results were observed with TTC $>10 \mathrm{ng} / \mathrm{mL}$, although the absolute number of TTC above $10 \mathrm{ng} / \mathrm{mL}$ was lesser (Figure 3a). In addition, we performed the same investigation during 13 - 36 months post-transplantation period (Figure 3b). Even the difference was less noticeable, except for TTC $>10 \mathrm{ng} / \mathrm{mL}$, it was still significant (Chi-Square $=9.853, p=0.043$ ). Still, average TTC during 6 - 12 months post-transplantation were not different in relation to IPV tertiles $(7.51 \mathrm{ng} / \mathrm{mL} v s$. 7. $39 \mathrm{ng} / \mathrm{mL}$ vs. $7.23 \mathrm{ng} / \mathrm{mL}, \mathrm{p}=0.688$ ).

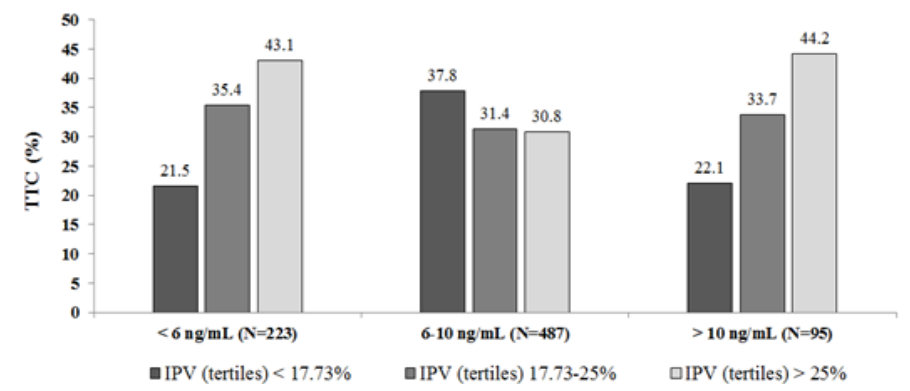

(a)

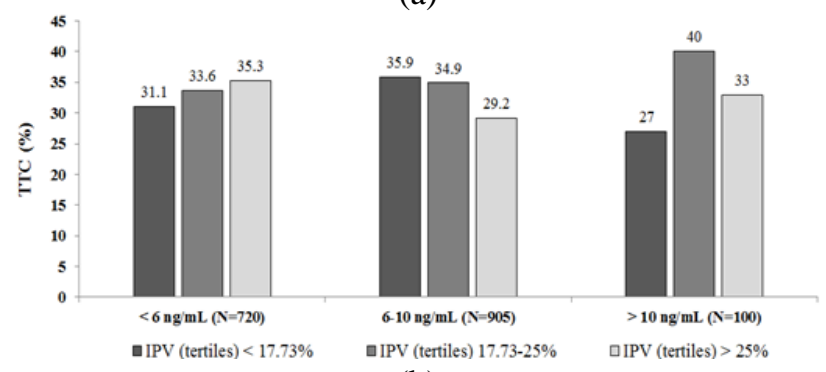

(b)

Figure 3.

Distribution of TTC beyond and within the therapeutic range in relation to Tac IPV tertiles groups from: (a) 6 months and up to 12 months after Tx $\left(\chi^{2}=25.175, \mathrm{p}<0.001\right)$; and (b) 13 months and up to 36 months after Tx

$$
\left(\chi^{2}=9.853, \mathrm{p}=0.043\right)
$$

Similar to our study, Goodall et al. also found that almost double the number of patients had a high IPV compared to a low IPV in the groups of patients with TTC out of therapeutic range (i.e. $<5 \mathrm{ng} / \mathrm{mL}$ and $>9 \mathrm{ng} / \mathrm{mL}$ ). Consequently, they revealed inferior dnDSA-free survival in patients' group with TTC $>9$ $\mathrm{ng} / \mathrm{mL}$ and high IPV than in patients with TTC $>9$ $\mathrm{ng} / \mathrm{mL}$ and low IPV (52.6\% vs. 93.8\%). Other allograft outcomes were comparable between high and low IPV within groups of different TTC [7].
Further, aiming to evaluate the influence of Tac bioavailability/exposure in the first year post-transplantation on graft function decline within three years after Tx, patients were divided into equal groups based on the median value of average Tac $\mathrm{C}_{0} / \mathrm{D}$ during 6 - 12 months post-transplantation $(\leq 1.56 \mathrm{ng} / \mathrm{mL} / \mathrm{mg}$ and $>1.56 \mathrm{ng} / \mathrm{mL} / \mathrm{mg}$ ). A significant change in eGFR was observed in the low $\mathrm{C}_{0} / \mathrm{D}$ group $(\mathrm{p}=0.013)$, whereby pairwise comparisons indicated a significant difference between 13 - 24 and 25 - 36 months after 
FARMACIA, 2020, Vol. 68, 6

Tx $\left(46.14 \pm 15.61 \mathrm{~mL} / \mathrm{min} / 1.73 \mathrm{~m}^{2}\right.$ vs. $43.62 \pm 16.12$ $\left.\mathrm{mL} / \mathrm{min} / 1.73 \mathrm{~m}^{2}, \mathrm{p}=0.010\right)$. There was no difference

between observed post-transplantation periods in the high $\mathrm{C}_{0} / \mathrm{D}$ group $(\mathrm{p}=0.161)$ (Figure 4$)$.

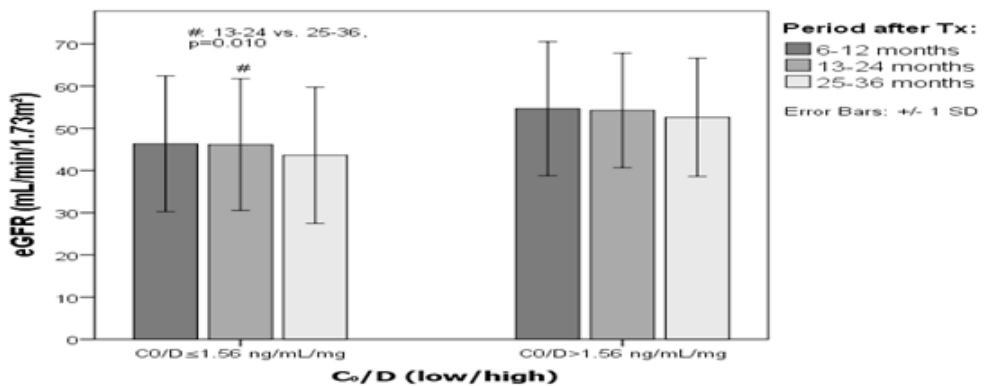

Figure 4.

Change in eGFR values in different periods after Tx with respect to Tac $\mathrm{C}_{0} / \mathrm{D}$ groups

Besides IPV, the obtained results showed that patients with average $\mathrm{C}_{0} / \mathrm{D} \leq 1.56 \mathrm{ng} / \mathrm{mL} / \mathrm{mg}$ from 6 to 12 months post-transplantation had a significant graft function decline between $2^{\text {nd }}$ and $3^{\text {rd }}$ year after Tx. A potential explanation for such a phenomenon can be attributed to lower bioavailability and exposure in this group of patients, which made them more prone to kidney injury. Besides, average $\mathrm{C}_{0} / \mathrm{D}$ is a better parameter of drug exposure comparison between patients than average TTC due to the high degree of variance of TTC and regularly applied TDM, to maintain its values within the target range. Studies demonstrated that under-immunosuppression within the first posttransplantation year is assumed to be an important cause of graft loss in the late period after Tx [3, 17, 20]. In addition, Gatault et al. suggested that in patients on extended formulation of Tac, TTC should be kept above $7 \mathrm{ng} / \mathrm{mL}$ during the first postoperative year in order to avoid rejection episodes [6]. A second glance at this finding, $\mathrm{C}_{0} / \mathrm{D}$ is assumed to be more parameter of dose requirements than the exposure of drug [14]. Therefore, lower $\mathrm{C}_{0} / \mathrm{D}$ implies a faster metabolism rate and higher TDD requirements to maintain TTC within the target range. Thölking et al. indicated that the Tac metabolism rate defined by $\mathrm{C}_{0} / \mathrm{D}$ impacts kidney function within a 24 months follow-up Tx, whereas fast rate metabolism was associated with a lower eGFR [28]. Kuypers et al. demonstrated the association between high Tac dose requirements and calcineurin inhibitor-associated nephrotoxicity [12] Schütte-Nütgen et al. reported, in a cohort of 401 kidney transplant recipients, that $\mathrm{C}_{0} / \mathrm{D}<1.05 \mathrm{ng} / \mathrm{mL} /$ $\mathrm{mg}$ at $3^{\text {rd }}$ month post-transplantation was associated with a more pronounced decline in eGFR following 5 years after Tx compared to $\mathrm{C}_{0} / \mathrm{D} \geq 1.05 \mathrm{ng} / \mathrm{mL} / \mathrm{mg}$, as well with a worse graft and patient survival [18]. Namely, this may suggest, that the minimization of TDD is more important than lowering TTC.

Table II

Tac pharmacokinetics parameters with respect to CYP3A5 genotype in different periods after Tx

\begin{tabular}{|c|c|c|c|}
\hline All patients & 6 - 12 months & 13 - 24 months & 25 - 36 months \\
\hline \multicolumn{4}{|l|}{ TDD (mg) } \\
\hline \multirow{2}{*}{ CYP 3 A5*1/*3 } & $6.70 \pm 3.72$ & $5.38 \pm 2.86$ & $4.80 \pm 2.90$ \\
\hline & $6.00(4.00-8.50)$ & $5.50(3.00-6.75)$ & $4.00(2.25-6.00)$ \\
\hline \multirow{2}{*}{ CYP3A5*3/*3 } & $4.66 \pm 2.81$ & $3.82 \pm 2.31$ & $3.43 \pm 2.07$ \\
\hline & $4.00(3.00-6.00)$ & $3.50(2.00-4.50)$ & $3.00(2.00-4.00)$ \\
\hline Sig. & $<0.001$ & $<0.001$ & $<0.001$ \\
\hline \multicolumn{4}{|l|}{ TTC $(\mathrm{ng} / \mathrm{mL})$} \\
\hline \multirow{2}{*}{ CYP3A5*1/*3 } & $7.75 \pm 2.67$ & $6.71 \pm 2.67$ & $6.07 \pm 2.24$ \\
\hline & $7.70(6.10-9.30)$ & $6.80(5.45-7.85)$ & $6.00(4.75-7.15)$ \\
\hline \multirow{2}{*}{ CYP 3 A $5 * 3 / * 3$} & $7.22 \pm 2.44$ & $6.66 \pm 2.44$ & $6.41 \pm 2.34$ \\
\hline & $7.10(5.60-8.70)$ & $6.60(5.20-8.00)$ & $6.30(5.10-7.70)$ \\
\hline Sig. & 0.022 & 0.593 & 0.179 \\
\hline \multicolumn{4}{|c|}{$\mathrm{C}_{0} / \mathrm{D}(\mathrm{ng} / \mathrm{mL} / \mathrm{mg})$} \\
\hline \multirow{2}{*}{ CYP3A5*1/*3 } & $1.38 \pm 0.65$ & $1.54 \pm 0.76$ & $1.58 \pm 0.82$ \\
\hline & $1.20(0.93-1.80)$ & $1.38(1.03-2.02)$ & $1.51(0.95-2.02)$ \\
\hline \multirow{2}{*}{ CYP 3 A $5 * 3 / * 3$} & $2.01 \pm 1.26$ & $2.23 \pm 1.39$ & $2.32 \pm 1.43$ \\
\hline & $1.63(1.18-2.43)$ & $1.85(1.32-2.70)$ & $2.00(1.45-2.76)$ \\
\hline Sig. & $<0.001$ & $<0.001$ & $<0.001$ \\
\hline
\end{tabular}

Data are expressed as mean \pm standard deviation and median (IQR)

TDD - tacrolimus daily dose; TTC - tacrolimus trough concentration; $\mathrm{C}_{0} / \mathrm{D}$ - dose-adjusted trough concentration 
FARMACIA, 2020, Vol. 68, 6

The obtained results showed that the carriers of CYP3A5*1/*3 genotype had higher TDD and lower $\mathrm{C}_{0} / \mathrm{D}$ compared to the carriers of CYP3A $5 * 3 / * 3$ genotype in the late period after Tx (Table II). Although, the carriers of ABCB1 3435 CC genotype had higher TDD and consequently TTC compared to the carriers of at least one T allele (ABCB1 $3435 \mathrm{CT}+\mathrm{TT}$ ), there was no difference in $\mathrm{C}_{0} / \mathrm{D}$ (Table III). Considering that CYP3A5 gene polymorphism may have interfered with these results, CYP3A5*1/*3 patients were excluded to assess independently the influence of ABCB1 3435 gene polymorphism on TDD, TTC, and $\mathrm{C}_{0} / \mathrm{D}$. The findings in the CYP3A $5 * 3 / * 3$ pool almost completely represented the entire study population, except for $\mathrm{C}_{0} / \mathrm{D}$ during 13 - 24 months post-transplantation, which was significant between groups.

Table III

Tac pharmacokinetics parameters with respect to ABCB1 3435 genotype in different periods after Tx

\begin{tabular}{|c|c|c|c|}
\hline All patients & 6 - 12 months & 13 - 24 months & 25 - 36 months \\
\hline TDD (mg) & & & \\
\hline \multirow{2}{*}{ ABCB1 $3435 \mathrm{CC}$} & $5.73 \pm 2.85$ & $4.57 \pm 2.44$ & $3.89 \pm 2.10$ \\
\hline & $5.00(3.50-7.50)$ & $4.00(3.00-6.00)$ & $4.00(2.00-5.00)$ \\
\hline \multirow{2}{*}{ ABCB1 3435 CT+TT } & $4.41 \pm 2.75$ & $3.65 \pm 2.24$ & $3.35 \pm 2.05$ \\
\hline & $4.00(3.00-5.00)$ & $3.25(2.00-4.00)$ & $3.00(2.00-4.00)$ \\
\hline Sig. & $<0.001$ & $<0.001$ & 0.005 \\
\hline \multicolumn{4}{|l|}{ TTC (ng/mL) } \\
\hline \multirow{2}{*}{ ABCB1 $3435 \mathrm{CC}$} & $8.04 \pm 2.01$ & $7.43 \pm 2.05$ & $7.08 \pm 2.29$ \\
\hline & $7.80(6.85-9.50)$ & $7.40(6.35-8.55)$ & $6.70(5.40-8.40)$ \\
\hline \multirow{2}{*}{ ABCB1 3435 CT+TT } & $7.03 \pm 2.49$ & $6.48 \pm 2.52$ & $6.29 \pm 2.33$ \\
\hline & $6.90(5.50-8.50)$ & $6.30(4.90-7.80)$ & $6.10(5.00-7.60)$ \\
\hline Sig. & $<0.001$ & $<0.001$ & 0.003 \\
\hline \multicolumn{4}{|l|}{$\mathrm{C}_{0} / \mathrm{D}(\mathrm{ng} / \mathrm{mL} / \mathrm{mg})$} \\
\hline \multirow{2}{*}{ ABCB1 $3435 \mathrm{CC}$} & $1.85 \pm 1.18$ & $2.18 \pm 1.59$ & $2.43 \pm 1.84$ \\
\hline & $1.53(1.08-2.22)$ & $1.75(1.23-2.32)$ & $2.05(1.33-2.88)$ \\
\hline \multirow{2}{*}{ ABCB1 3435 CT+TT } & $2.05 \pm 1.27$ & $2.24 \pm 1.39$ & $2.30 \pm 1.34$ \\
\hline & $1.66(1.20-2.48)$ & $1.86(1.33-2.77)$ & $2.00(1.46-2.75)$ \\
\hline Sig. & 0.071 & 0.098 & 0.868 \\
\hline CYP3A5*3/*3 patients & 6 - 12 months & 13 - 24 months & 25 - 36 months \\
\hline \multicolumn{4}{|l|}{ TDD (mg) } \\
\hline \multirow{2}{*}{ ABCB1 $3435 \mathrm{CC}$} & $5.44 \pm 2.64$ & $4.49 \pm 2.14$ & $3.88 \pm 2.02$ \\
\hline & $5.00(3.88-6.00)$ & $4.00(3.00-6.00)$ & $4.00(2.00-5.00)$ \\
\hline \multirow{2}{*}{ ABCB1 $3435 \mathrm{CT}+\mathrm{TT}$} & $4.47 \pm 2.60$ & $3.66 \pm 2.26$ & $3.37 \pm 2.08$ \\
\hline & $4.00(2.75-5.43)$ & $3.00(2.00-4.00)$ & $3.00(2.00-4.00)$ \\
\hline Sig. & $<0.001$ & $<0.001$ & 0.003 \\
\hline \multicolumn{4}{|l|}{ TTC (ng/mL) } \\
\hline \multirow{2}{*}{ ABCB1 $3435 \mathrm{CC}$} & $7.92 \pm 1.06$ & $7.38 \pm 2.04$ & $7.05 \pm 2.29$ \\
\hline & $7.80(7.17-8.36)$ & $7.40(6.20-8.50)$ & $4.00(5.40-8.40)$ \\
\hline \multirow{2}{*}{ ABCB1 $3435 \mathrm{CT}+\mathrm{TT}$} & $6.98 \pm 1.63$ & $6.48 \pm 2.53$ & $6.27 \pm 2.34$ \\
\hline & $6.94(6.24-8.01)$ & $6.30(4.90-7.80)$ & $3.00(5.00-7.60)$ \\
\hline Sig. & $<0.001$ & $<0.001$ & 0.003 \\
\hline \multicolumn{4}{|l|}{$\mathrm{C}_{0} / \mathrm{D}(\mathrm{ng} / \mathrm{mL} / \mathrm{mg})$} \\
\hline \multirow{2}{*}{ ABCB1 $3435 \mathrm{CC}$} & $1.86 \pm 0.95$ & $2.15 \pm 1.57$ & $2.42 \pm 1.83$ \\
\hline & $1.70(1.21-2.48)$ & $1.70(1.20-2.30)$ & $1.70(1.28-2.88)$ \\
\hline \multirow{2}{*}{ ABCB1 $3435 \mathrm{CT}+\mathrm{TT}$} & $1.93 \pm 0.97$ & $2.24 \pm 1.32$ & $2.27 \pm 1.30$ \\
\hline & $1.59(1.28-2.12)$ & $1.88(1.33-2.80)$ & $1.88(1.45-2.75)$ \\
\hline Sig. & 0.131 & 0.037 & 0.885 \\
\hline
\end{tabular}

Data are expressed as mean \pm standard deviation and median (IQR)

TDD - tacrolimus daily dose; TTC - tacrolimus trough concentration; $\mathrm{C}_{0} / \mathrm{D}$ - dose-adjusted trough concentration

This study confirmed that CYP $3 \mathrm{~A} 5 * 1 / * 3$ patients required higher TDD to maintain optimal immunosuppression (lower $\mathrm{C}_{0} / \mathrm{D}$ values) not only in the early post-transplantation period, but in the later periods as well, suggesting its potential connection with eGFR. Although, there is a strong association between CYP3A5*1/*3 and lower average $\mathrm{C}_{0} / \mathrm{D}$ from 6 to 12 month post-transplantation, it was suggested that not only CYP3A5 contributes to lower $\mathrm{C}_{0} / \mathrm{D}$ values, but other factors were involved as well [18]. Considering the ABCB1 genotype, an association of ABCB1 3435 $\mathrm{CC}$ genotype with higher TDD and TTC, but not $\mathrm{C}_{0} / \mathrm{D}$ was observed. In order to exclude potential interference of the CYP3A5 genotype [26], we examined the effects of ABCB1 3435 genotype separately in CYP3A $5 * 3 / * 3$ genotype carriers, but results were consistent. Our results are consistent with the observation that ABCB1 $3435 \mathrm{CC}$ genotype carriers have higher dose requirements to exert pharmacodynamic effects compared to the carriers of T allele. On the other side, 
FARMACIA, 2020, Vol. 68, 6

lower $\mathrm{ABCB} 1$ expression (ABCB1 3435 TT genotype) is related to the Tac-induced nephrotoxicity in most studies, especially when combined with the donor ABCB1 3435TT [27].

Univariate and multivariate linear regression analysis was performed to evaluate and confirm the effects of Tac-related factors on eGFR in the late posttransplantation period (from 13 months and up to 36 months). Estimated GFR was the dependent variable, whereby Tac pharmacokinetic-related factors (average TTC during 6 - 12 months, average $\mathrm{C}_{0} / \mathrm{D}$ during 6 - 12 months, IPV, CYP3A5, and ABCB1), eGFR at $6^{\text {th }}$ month post-transplantation, acute rejection within the first year, delayed graft function, age and sex represented the independent covariates (Table IV).

Univariate regression analysis of factors influencing the eGFR values from 13 months and up to 36 months after Tx

\begin{tabular}{|c|c|c|c|c|c|}
\hline MODEL & B (CI for B) & Beta & Sig. ${ }^{1}$ & $\mathbf{R}^{2}(\%)$ & Sig. ${ }^{2}$ \\
\hline \multicolumn{6}{|l|}{ Single predictor model } \\
\hline eGFR at 6 months $\left(\mathrm{mL} / \mathrm{min} / 1.73 \mathrm{~m}^{2}\right)$ & $\begin{array}{c}0.802 \\
(0.768-0.837)\end{array}$ & 0.741 & $<0.001$ & 55.0 & $<0.001$ \\
\hline Type of Tx (LDT: constant) & $\begin{array}{c}49.284 \\
(48.363-50.205)\end{array}$ & / & $<0.001$ & \multirow{2}{*}{0.1} & \multirow{2}{*}{0.150} \\
\hline Type of Tx (DDT vs. LDT) & $\begin{array}{c}1.308 \\
(-0.474-3.090)\end{array}$ & 0.035 & 0.150 & & \\
\hline Tac IPV\% (absolute value) & $\begin{array}{c}-0.158 \\
(-0.248-(-) 0.069)\end{array}$ & -0.083 & 0.001 & 0.7 & 0.001 \\
\hline Tac IPV (tertile 1: constant) & $\begin{array}{c}51.910 \\
(50.543-53.277) \\
\end{array}$ & / & $<0.001$ & \multirow{3}{*}{0.9} & \multirow{3}{*}{$<0.001$} \\
\hline Tac IPV (tertile 2 vs. tertile 1 ) & $\begin{array}{c}-3.720 \\
(-5.623-(-) 1.816)\end{array}$ & -0.106 & $<0.001$ & & \\
\hline Tac IPV (tertile 3 vs. tertile 1 ) & $\begin{array}{c}-3.041 \\
(-4.992-(-) 1.090)\end{array}$ & -0.085 & 0.002 & & \\
\hline CYP3A5 $(* 3 / * 3$ genotype: constant $)$ & $\begin{array}{c}51.025 \\
(50.191-51.860)\end{array}$ & l & $<0.001$ & \multirow{2}{*}{4.1} & \multirow{2}{*}{$<0.001$} \\
\hline CYP3A5 $(* 1 / * 3$ vs. $* 3 / * 3$ genotype) & $\begin{array}{c}-9.669 \\
(-11.870-(-) 7.468)\end{array}$ & -0.203 & $<0.001$ & & \\
\hline Sex (female: constant) & $\begin{array}{c}46.928 \\
(45.673-48.184)\end{array}$ & l & $<0.001$ & \multirow{2}{*}{1.7} & \multirow{2}{*}{$<0.001$} \\
\hline Sex (male $v s$. female) & $\begin{array}{c}4.423 \\
(2.818-6.028)\end{array}$ & 0.129 & $<0.001$ & & \\
\hline ABCB1 genotype (CC: constant) & $\begin{array}{c}50.762 \\
(49.227-52.296)\end{array}$ & l & $<0.001$ & \multirow{2}{*}{0.2} & \multirow{2}{*}{0.093} \\
\hline $\mathrm{ABCB} 1$ genotype (CT+TT vs. CC) & $\begin{array}{c}-1.532 \\
(-3.321-0.257)\end{array}$ & -0.040 & 0.093 & & \\
\hline Age (years) & $\begin{array}{c}-0.192 \\
(-0.265-(-) 0.118)\end{array}$ & -0.122 & $<0.001$ & 1.5 & $<0.001$ \\
\hline Mean TTC from 6 - 12 months (ng/mL) & $\begin{array}{c}-0.334 \\
(-0.822-0.153) \\
\end{array}$ & -0.032 & 0.179 & 0.1 & 0.179 \\
\hline Mean $\mathrm{C}_{0} / \mathrm{D}$ from 6 - 12 months $(\mathrm{ng} / \mathrm{mL} / \mathrm{mg}$ ) & $\begin{array}{c}2.342 \\
(1.523-3.161)\end{array}$ & 0.134 & $<0.001$ & 1.8 & $<0.001$ \\
\hline Delayed graft function (no: constant) & $\begin{array}{c}49.898 \\
(49.058-50.737)\end{array}$ & l & $<0.001$ & \multirow{2}{*}{0.2} & \multirow{2}{*}{0.075} \\
\hline Delayed graft function (yes vs. no) & $\begin{array}{c}-2.209 \\
(-4.640-0.222)\end{array}$ & -0.043 & 0.075 & & \\
\hline Acute graft rejection (no: constant) & $\begin{array}{c}50.414 \\
(49.621-51.207)\end{array}$ & l & $<0.001$ & \multirow{2}{*}{4.1} & \multirow{2}{*}{$<0.001$} \\
\hline Acute graft rejection (yes vs. no) & $\begin{array}{c}-15.345 \\
(-18.863-(-) 11.827)\end{array}$ & -0.202 & $<0.001$ & & \\
\hline
\end{tabular}

$\mathrm{B}-$ unstandardized regression coefficient; CI - 95\% confidence interval; Beta - standardized regression coefficient; $\mathrm{R}$ squared - proportion of the variance around the mean of the eGFR that is explained by the present model; ${ }^{1}$ - The significance of the predictor within a proposed model $;^{2}$ - The significance of the proposed model itself; DDT - deceased donor Tx; LDT - living donor Tx; IPV - intra-individual variability; TTC - tacrolimus trough concentration; $\mathrm{C}_{0} / \mathrm{D}$ - dose-adjusted trough concentration

The multivariate linear regression analysis confirmed that Tac IPV and acute rejection had a negative impact, while $\mathrm{C}_{0} / \mathrm{D}$ was positively associated with eGFR in the observed period (Table V). Although a significant predictor in univariate analysis, the CYP3A5 genotype was excluded from the multivariate analysis due to the correlation with $\mathrm{C}_{0} / \mathrm{D}$. If omitted the eGFR at 6 months from the analysis, predictors of interest contributed with $12.1 \%$ variability in eGFR. 
Multivariate regression analysis of factors influencing the eGFR values from 13 months and up to 36 months

\begin{tabular}{|c|c|c|c|c|c|}
\hline MODEL & B (CI for B) & Beta & Sig. ${ }^{1}$ & $\mathbf{R}^{2}(\%)$ & Sig. $^{2}$ \\
\hline Multivariate analysis/predicators & & & & & \\
\hline eGFR at 6 months $\left(\mathrm{mL} / \mathrm{min} / 1.73 \mathrm{~m}^{2}\right)$ & $\begin{array}{c}0.765 \\
(0.730-0.800)\end{array}$ & 0.707 & $<0.001$ & \multirow{6}{*}{57.4} & \multirow{6}{*}{$<0.001$} \\
\hline Tac IPV (tertile $2 v s$. tertile 1 ) & $\begin{array}{c}-1.764 \\
(-3.057-(-) 0.470)\end{array}$ & -0.050 & 0.008 & & \\
\hline Tac IPV (tertile $3 v s$. tertile 1 ) & $\begin{array}{c}-2.418 \\
(-3.764-(-) 1.071)\end{array}$ & -0.067 & $<0.001$ & & \\
\hline Sex (male $v s$. female) & $\begin{array}{c}1.419 \\
(0.284-2.555)\end{array}$ & 0.041 & 0.014 & & \\
\hline Age (years) & $\begin{array}{c}-0.018 \\
(-0.068-0.033)\end{array}$ & -0.011 & 0.498 & & \\
\hline Mean $\mathrm{C}_{0} / \mathrm{D}$ from 6 - 12 months $(\mathrm{ng} / \mathrm{mL} / \mathrm{mg})$ & $\begin{array}{c}1.608 \\
(0.994-2.222)\end{array}$ & 0.092 & $<0.001$ & & \\
\hline Acute graft rejection (yes $v s$. no) & $\begin{array}{c}-9.770 \\
(-12.343-(-) 7.197)\end{array}$ & -0.128 & $<0.001$ & & \\
\hline
\end{tabular}

B - unstandardized regression coefficient; CI - 95\% confidence interval; Beta - standardized regression coefficient; R squared - proportion of the variance around the mean of the eGFR that is explained by the present model; ${ }^{1}$ - The significance of the predictor within a proposed model; ${ }^{2}$ - The significance of the proposed model itself; IPV - intra-individual variability; $\mathrm{C}_{0} / \mathrm{D}$ - dose-adjusted trough concentration

To the best of our knowledge, this is the first study that assesses the influence of IPV and $\mathrm{C}_{0} / \mathrm{D}$ on graft function in kidney transplant recipients who still did not undergo dialysis or re-transplantation, intending to detect high-risk patients for graft loss. Goodall et al. had previously established that the highest IPV patients' group and TTC $<5 \mathrm{ng} / \mathrm{mL}$ (i.e. lower exposure) were negatively and independently associated with graft loss [7]. Shuker et al. found a similar association between increased Tac IPV and/or decreased TTC values and poor Tx outcomes, suggesting that in patients with a high IPV should be pursued to the achievement of higher TTC ( $\geq 7 \mathrm{ng} / \mathrm{mL}$ ) [20]. The present study demonstrated that high IPV, lower average $\mathrm{C}_{0} / \mathrm{D}$ from 6 to 12 months post-transplantation, and acute rejection episodes within the first year were independent predictors of worse eGFR values between 13 and 36 months after Tx. Conversely, average TTC during 6 - 12 months post-transplantation did not express the significant influence on long-term eGFR. The causal relationship between high IPV and worse kidney function is not entirely elucidated. Namely, high IPV may lead to subtherapeutic concentrations that consequently trigger under-immunosuppression and acute rejection episodes. Acute rejection per se is an important predictor of adverse Tx outcomes, whereby management of these episodes can provoke high IPV. Whalen et al. observed worse eGFR values at 1, 2, 3, and 4 years after Tx in patients with high IPV, and that association was independent of acute rejection episodes, that is in concordance with our results (Table V) [32]. Seibert et al. noticed that high variability of TTD increased the risk of acute rejection, whereas high variability of TTC increased the risk of graft failure [19]. Regarding the aforementioned role of the $\mathrm{C}_{0} / \mathrm{D}$ as the indicator of dose requirements and evident association of CYP3A5 genotype with TDD, we excluded the CYP3A5 genotype from multivariate analysis due to possible interference between these two variables.

In most of the previously published studies, authors have followed up patients since they reached the composite primary and secondary endpoint, i.e. graft failure or graft loss. Vanhove et al. were the first to examine the relation between high Tac IPV and the progression of chronic histologic lesions. Namely, they proved that patients with high IPV had an increased risk of moderate to severe fibrosis and tubular atrophy, before the onset of any kidney dysfunction and/or proteinuria using paired protocol biopsies at 3 months and 2 years [30]. We also did not aim for an outcome to occur, but instead followed patients with still functioning graft (i.e. without the need for dialysis or re-transplantation) in a three-year follow-up period. Some limitations of the study need to be mentioned. The drawback of the present research was the small number of patients and therefore a small number of patients per IPV group. Still, this is a single-centre study design and included 2530 patients' examinations and data derived from it. However, according to our knowledge, this was the first study on kidney transplant recipients with still functioning graft which assessed the $\mathrm{C}_{0} / \mathrm{D}$ and IPV, with an additional focus on genetic factors influencing Tac pharmacokinetics.

\section{Conclusions}

In conclusion, this study shows that high Tac IPV and lower $\mathrm{C}_{0} / \mathrm{D}$ may contribute to significant eGFR decline in three-year period following Tx. It was shown that the kidney function in the late period after Tx may be independently and negatively affected by these parameters alongside with acute rejection and kidney function at 6 months post-transplantation. Also, it 
seems that the influence of IPV on graft function is not independent, but more likely it leads to underand/or over-immunosuppression, which can be assumed as the risk factors for chronic rejection or nephrotoxicity. Moreover, the carriers of CYP $3 \mathrm{~A} 5 * 1$ allele may require higher TDD to maintain optimal immunosuppression in the later post-transplantation periods, thus influencing lower $\mathrm{C}_{0} / \mathrm{D}$ values compared to the CYP $3 A 5 * 3 / * 3$ carriers. Tailoring Tac treatment based on IPV, $\mathrm{C}_{0} / \mathrm{D}$ and CYP3A5 genotype in clinical practice may identify patients at risk for graft function decline, and thus achieve better outcomes in the late period after Tx.

\section{Acknowledgement}

This study was supported by Ministry of Education, Science and Technological Development of Serbiaproject number III41018.

\section{Conflict of interest}

The authors declare no conflict of interest.

\section{References}

1. Andrews LM, Li Y, De Winter BCM, Shi YY, Baan CC, Van Gelder T, Hesselink DA, Pharmacokinetic considerations related to therapeutic drug monitoring of tacrolimus in kidney transplant patients. Expert Opin Drug Metab Toxicol., 2017; 13(12): 1225-1236.

2. Ashavaid TF, Raje HS, Shah BV, Shah SA, Design of Allele Specific PCR for Rapid Detection of CYP3A5 (A6986G) and Mdr-1 (C3435T) Polymorphisms. Indian J Clin Biochem., 2011; 26(1): 18-21.

3. Baker RJ, Mark PB, Patel RK, Stevens KK, Palmer N, Renal association clinical practice guideline in postoperative care in the kidney transplant recipient. BMC Nephrol., 2017; 18(1): 174: 1-41.

4. Borra LC, Roodnat JI, Kal JA, Mathot RA, Weimar W, van Gelder T, High within-patient variability in the clearance of tacrolimus is a risk factor for poor long-term outcome after kidney transplantation. Nephrol Dial Transplant., 2010; 25(8): 2757-2763.

5. Cusinato DAC, Lacchini R, Romao EA, MoysésNeto M, Coelho EB, Relationship of Cyp3a5 Genotype and Abcb1 Diplotype to Tacrolimus Disposition in Brazilian Kidney Transplant Patients. $\mathrm{Br} \mathrm{J}$ Clin Pharmacol., 2014; 78(2): 364-372.

6. Gatault P, Kamar N, Büchler M, Colosio C, Bertrand D, Durrbach A, Albano L, Rivalan J, Le Meur Y, Essig M, Bouvier N, Legendre C, Moulin B, Heng AE, Weestel PF, Sayegh J, Charpentier B, Rostaing L, Thervet E, Lebranchu Y, Reduction of ExtendedRelease Tacrolimus Dose in Low-ImmunologicalRisk Kidney Transplant Recipients Increases Risk of Rejection and Appearance of Donor-Specific Antibodies: A Randomized Study. Am J Transplant., 2017; 17(5): 1370-1379.

7. Goodall DL, Willicombe M, McLean AG, Taube D, High Intrapatient Variability of Tacrolimus Levels and Outpatient Clinic Nonattendance Are Associated
With Inferior Outcomes in Renal Transplant Patients. Transplant Direct, 2017; 3(8): e192: 1-9.

8. Hart A, Smith JM, Skeans MA, Gustafson SK, Wilk AR, Robinson A, Wainright JL, Haynes CR, Snyder JJ, Kasiske BL, Israni AK, OPTN/SRTR 2016 Annual Data Report: Kidney. Am J Transplant., 2018; 18 (Suppl 1): 18-113.

9. Hesselink DA, Bouamar R, Elens L, van Schaik RH, van Gelder T, The role of pharmacogenetics in the disposition of and response to tacrolimus in solid organ transplantation. Clin Pharmacokinet., 2014; 53(2): 123-139.

10. Kaya Aksoy G, Comak E, Koyun M, Akbaş H, Akkaya B, Aydınlı B, Uçar F, Akman S, Tacrolimus Variability: A Cause of Donor-Specific Anti-HLA Antibody Formation in Children. Eur J Drug Metab Pharmacokinet., 2019; 44(4): 539-548.

11. Kotowski M, Bogacz A, Bartkowiak-Wieczorek J, Sienko J, Tejchman K, Dziewanowski K, Ostrowski M, Czerny B, Grześkowiak E, Machaliński B, Effect of interleukin-6 polymorphism on function of the renal allograft funtion and efficacy of immunosuppressive therapy. Farmacia, 2018; 66(5): 791-797.

12. Kuypers DR, Naesens M, de Jonge H, Lerut E, Verbeke $\mathrm{K}$, Vanrenterghem Y, Tacrolimus dose requirements and CYP3A5 genotype and the development of calcineurin inhibitor-associated nephrotoxicity in renal allograft recipients. Ther Drug Monit., 2010; 32(4): 394-404.

13. Kuypers DRJ, "What do we know about tacrolimus pharmacogenetics in transplant recipients?". Pharmacogenomics, 2018; 19(7): 593-597.

14. Kuypers DRJ, Intrapatient Variability of Tacrolimus Exposure in Solid Organ Transplantation: A Novel Marker for Clinical Outcome. Clin Pharmacol Ther., 2020; 107(2): 347-358.

15. Levey AS, Coresh J, Greene T, Stevens LA, Zhang YL, Hendriksen S, Kusek JW, Van Lente F, Chronic Kidney Disease Epidemiology Collaboration, Using standardized serum creatinine values in the modification of diet in renal disease study equation for estimating glomerular filtration rate. Ann Intern Med., 2006; 145(4): 247-254.

16. Press RR, de Fijter JW, Guchelaar HJ, Individualizing calcineurin inhibitor therapy in renal transplantation current limitations and perspectives. Curr Pharm Des., 2010; 16(2): 176-186.

17. Rodrigo E, Segundo DS, Fernández-Fresnedo G, López-Hoyos M, Benito A, Ruiz JC, de Cos MA, Arias M, Within-Patient Variability in Tacrolimus Blood Levels Predicts Kidney Graft Loss and DonorSpecific Antibody Development. Transplantation, 2016; 100(11): 2479-2485.

18. Schütte-Nütgen K, Thölking G, Steinke J, Pavenstädt H, Schmidt R, Suwelack B, Reuter S, Fast Tac Metabolizers at Risk - It is Time for a C/D Ratio Calculation. $J$ Clin Med., 2019; 8(5): 587: 1-15.

19. Seibert SR, Schladt DP, Wu B, Guan W, Dorr C, Remmel RP, Matas AJ, Mannon RB, Israni AK, Oetting WS, Jacobson PA, Tacrolimus trough and dose intra-patient variability and CYP3A5 genotype: Effects on acute rejection and graft failure in European American and African American kidney transplant 
recipients. Clin Transplant., 2018; 32(12): e13424: $1-22$.

20. Shuker N, Shuker L, van Rosmalen J, Roodnat JI, Borra LCP, Weimar W, Hesselink DA, van Gelder T, A high intrapatient variability in tacrolimus exposure is associated with poor long-term outcome of kidney transplantation. Transpl Int., 2016; 29(11): 1158-1167.

21. Shuker N, van Gelder T, Hesselink DA, Intrapatient variability in tacrolimus exposure: causes, consequences for clinical management. Transplant Rev (Orlando), 2015; 29(2): 78-84.

22. Staatz CE, Goodman LK, Tett SE, Effect of CYP3A and $\mathrm{ABCB} 1$ single nucleotide polymorphisms on the pharmacokinetics and pharmacodynamics of calcineurin inhibitors: Part I. Clin Pharmacokinet., 2010; 49(3): 141-175.

23. Staatz CE, Tett SE, Clinical pharmacokinetics and pharmacodynamics of tacrolimus in solid organ transplantation. Clin Pharmacokinet., 2004; 43(10): 623-653.

24. Stefanović NZ, Cvetković TP, Jevtović-Stoimenov TM, Ignjatović AM, Paunović GJ, VeličkovićRadovanović RM, Investigation of CYP 3A5 and $\mathrm{ABCB} 1$ gene polymorphisms in the long-term following renal transplantation: Effects on tacrolimus exposure and kidney function. Exp Ther Med., 2015; 10(3): 1149-1156.

25. Süsal C, Döhler B, Late intra-patient tacrolimus trough level variability as a major problem in kidney transplantation: A Collaborative Transplant Study Report. Am J Transplant., 2019; 19(10): 2805-281.

26. Sy SK, Singh RP, Shilbayeh S, Zmeili R, Conrado D, Derendorf $\mathrm{H}$, Influence of CYP3A5 6986A $>\mathrm{G}$ and ABCB1 3435C > T Polymorphisms on Adverse Events Associated With Tacrolimus in Jordanian Pediatric
Renal Transplant Patients. Clin Pharmacol Drug Dev., 2013; 2(1): 67-78.

27. Tang JT, Andrews LM, van Gelder T, Shi YY, van Schaik RHN, Wang LL, Hesselink DA, Pharmacogenetic aspects of the use of tacrolimus in renal transplantation: recent developments and ethnic considerations. Expert Opin Drug Metab Toxicol., 2016; 12(5): 555-565.

28. Thölking G, Fortmann C, Koch R, Gerth HU, Pabst D, Pavenstädt H, Kabar I, Hüsing A, Wolters H, Reuter $\mathrm{S}$, Suwelack B, The tacrolimus metabolism rate influences renal function after kidney transplantation. PLoS One, 2014; 9(10): e111128: 1-8.

29. Tron C, Lemaitre F, Verstuyft C, Petitcollin A, Verdier M, Bellissant E, Pharmacogenetics of Membrane Transporters of Tacrolimus in Solid Organ Transplantation. Clin Pharmacokinet., 2019; 58: 593-613.

30. Vanhove T, Vermeulen T, Annaert P, Lerut E, Kuypers DRJ. High Intrapatient Variability of Tacrolimus Concentrations Predicts Accelerated Progression of Chronic Histologic Lesions in Renal Recipients. Am J Transplant., 2016; 16(10): 2954-2963.

31. Velickovic-Radovanovic R, Mikov M, Catic-Djordjevic A, Stefanovic N, Mitic B, Paunovic G, Cvetkovic $\mathrm{T}$, Gender-dependent predictable pharmacokinetic method for tacrolimus exposure monitoring in kidney transplant patients. Eur J Drug Metab Pharmacokinet., 2015; 40(1): 95-102.

32. Whalen HR, Glen JA, Harkins V, Stevens KK, Jardine AG, Geddes CC, Clancy MJ, High Intrapatient Tacrolimus Variability Is Associated With Worse Outcomes in Renal Transplantation Using a Low-Dose Tacrolimus Immunosuppressive Regime. Transplantation, 2017; 101(2): 430-436. 